\title{
AN ACCOUNT ON MYXOMYCETES FROM KATHMANDU VALLEY, NEPAL
}

\author{
A.B. Chauhan ${ }^{1}$, U. Budhathoki ${ }^{2}$ and M.K. Adhikari ${ }^{3}$
}

\begin{abstract}
This paper reports on 11 species of myxomycetes (Arcyria pomiformis, Arcyria incarnata, Arcyria cineria, Stemoitis sp., Didymium flexuosum, Physarum viride. Hemitrichia serpula, Tubifera microsperma, Fuligo cinerea, Mucilago crustacea and Didymium iridis) gathered in 2006-2008 from the adjoining hills (Shivapuri and Godavari) around the Kathmandu valley. Further studies on the phytogeographic relationship, frequency and dominance of the taxa need to be carried out in future.
\end{abstract}

Key words: Myxomycetes, Kathmandu Valley, Nepal

\section{INTRODUCTION}

The vegetation of the Kathmandu Valley comprises of Schima-Castanopsis - Castanopsis forest at lower elevation and Quercus-Laurel and Quercus-Rhododendron forest at the upper elevation. The forest ground has abundant number of substrates (logs, decayed, leaves, humid and damp soil). The climate is cool subtropical to warm temperate. This type of vegetation and climate is suitable to grow species of Myxomycetes.

Some studies on Myxomycetes in Nepal have been done by Poelt (1965), Bhatt (1966), Singh (1971), Onsberg (1973), Singh and Singh (1976), Singh et al. (1977), Hagiwara and Bhandary (1982), Yamamoto and Hagiwara (1990) and Nannenga-Bremekamp and Yamamoto (1988). Based on the studies; the check reference list and historical account of Myxomycetes have been reported (Adhikari and Manandhar 1996, Adhikari 2009). A book entitled "Myxomycetes in Nepal" has been published (Adhikari 2012).

The literature reviewes included a total of 26 species of Myxomycetes from Kathmandu Valley (Godawari, Phulchowki, Patan, Thankot, Gokarna, Hattiban, Kamalpokhari, Baneswar, Putali sadak, Swayambhu). Among the reported species, the richest genera were Arcyria (8 spp.), Stemonitis (7 spp.) and Physarum (3 spp.). The rest genera (Badhamia, Clastoderma, Cribraria, Diderma, Didymium, Hemitrichia, Physerella) had one species each. Three species (Arcyria insignis, Clastoderma pulchella and Physarum wingatense) were reported from Godavari and two species (Arcyria cinerea and Cribraria microcarpa) from Phulchowki.

Very little work has been carried out on Myxomycetes from Godavari. But there is no report of Myxomycetes from Shivapuri. Therefore; this study has been conducted in Shivapuri and Godavari (Phulchowki).

\section{MATERIALS AND METHODS}

The study was conducted following the standard methods in August 2006, August to September 2007 and July 2008 in the hills of Shivapuri and Godavari. Specimens were collected and identified in National Herbarium, Godavari and Central Department of Botany, Kirtipur. All the specimens were housed in the Central Department of Botany, Tribhuvan University; Kirtipur; Kathmandu, Nepal. 


\section{ENUMERATION OF MYXOMYCETES}

The scientific names of the species is followed by major reference, habitat, location, year of collection, collection number, collector and distribution. Some species were illustrated (Annex 1).

Arcyria cinerea (Bull) Pers., 1801. in Emoto. The Myxomycetes of Japan. 62, 1977. pl. 31.

On wood bark, Shivapuri, 2006/8/3, no. 16, A. Chauhan

Distribution- Cosmopolitan

Arcyria incarnata Pers,, 1875, Pamietu Towartz Nauk Sci Paryzu 6 (1): 278; Emoto. The Myxomycetes of Japan. 64, 1977. pl. 32.

On rotten wood or falling twigs, Shivapuri, 2006/8/3, no. 05, A. Chauhan

Distribution - Cosmopolitan.

Arcyria pomiformis (Leers.) Rostof. in Ferr, 1962 Mycologic 54: 516 - 530; Emoto. The Myxomycetes of Japan. 64, 1977. pl. 32.

On rotten wood or on rotten bark place of tree, Shivapuri, 2006/8/3, no.01, A. Chauhan .

Distribution: Comopolitan.

Didyamium flexuosum Yamashiro Lin, Citt. \& Y. E. Chen. Taiwania. 43 (178): 177-184, 1998; Emoto. The Myxomycetes of Japan. 236, 1977. pl. 118.

On fallen leaves, Sivapuri, 2006/8/20, no. 07; on rotten wood, Godavary, 2007/9/1, no. 25, A. Chauhan.

Distribution - Japan and Nepal.

Didymium iridis (Ditmar) Fr. Wang et al. Biol Bull. Nat (Taiman. Normal Umi 16: 8 (1-12), Publication Year; Emoto. The Myxomycetes of Japan. 240, 1977. pl. 120.

On fallen leaves, Shivapuri, 2006/8/3, no. 35, A. Chauhan.

Distribution - World wide.

Fuligo cinerea (Schw.) Morgan. in Emoto, The Myxomycetes of Japan. 138: 1977. pl. 69.

On fallen leaves or twings Shivapuri, 2008/7/ 4, no. 27, A. Chauhan.

Distribution - Cosmopolitan.

Hemitrichia serpula (Scap.) Rost. in Emoto, The Myxomucetes of Japan. 94; 1977, pl- 47. on rotten wood, Shivapuri 2007/9/1, no. 11, A. Chauhan; on rotten wood, Godavary, 2007/9/1, no. 06, A. Chauhan

Distribution - Cosmopolitan.

Mucilage crustacea Wiggers. in Emoto, The Myxomycetes of Japan. 230: 1977. pl. 115.

On fallen leaves, Shivapuri, 2007/8/4, no. 32, A. Chauhan.

Distribution: World wide.

Physarum viride (Bull.) Pers.. in Emoto, The Myxomycetes of Japan.170, 1977. pl. 85.

On rotten wood, Shivapuri, 2007/9/1, no. 10, A. Chauhan.

Distribution: Cosmopolitan. 
Stemonitis cinerea (Bull.) J.F. Grnel, 1782. in Emoto, The Myxomycetes of Japan. 62, 1977. pl. 31.

On rotten wood, Godavari, 2006/8/10, no. 04, A. Chauhan.

Distribution - Cosmopolitan.

Tubifera ferruginosa (Batsch.) Gmelin, 1947: Taxonomic notes on Myxomycetes. 11. MycoIogia, 39: 453-462, 1947, in Emoto, The Myxomycetes of Japan 16: 1977. pl. 8.

On rotten wood, Shivapuri, 2007/8/4, no. 45; on rotten wood, Godavari, 2007/9/1, no. 20, A. Chauhan.

Distribution - World wide.

\section{RESULTS AND DISCUSSION}

Among the 11 species,10 and 4 species of Myxomycetes were collected from Shivapuri and Godawari, respectively. Of the total species, three species (Didyamium flexuosum, Hemitrichia serpula and Tubifera ferruginosa) were common to Shivapuri and Godavari; 7 species (Arcyria pomiformis, Arcyria incarnata, Arcyria cinerea, Didymium iridis, Fuligo cinerea, Mucilage crustacea and Physarum viride) collected from Shivapuri only and one species (Stemonitis cinerea) from Godavari only. Of the total species, eight species (Arcyria pomiformis (Leers.) Rostof., Didyamium flexuosum Yamashiro, Didymium iridis (Ditmar) Fr., Fuligo cinerea (Schw.) Morgan, Mucilage crustacea Wiggers., Physarum viride (Bull.) Pers., Stemonitis cinerea (Bull.) J.F. Grnel, and Tubifera ferruginosa (Batsch.) Gmelin) were not reported previously from Kathmandu Valley and three species (Arcyria cinerea (Bull.) Pers., Arcyria incaranta Pers. and Hemitrichia serpula (Scop.) Rost. were reported from Kathmandu Valley other than Godavari and Shivapuri (Singh and Singh 1976, (Singh et al. 1977, Singh and Singh 1976, Yamamoto and Hagiwara 1990). This study added new species of Myxomycetes to the Kathmandu Valley. Further intensive exploration is necessary to prepare comprehensive list of species of and understand floristic diversity, phytogoegraphical correlation and the distribution pattern of Myxomycetes of Kathmandu Valley.

\section{ACKNOWLEDGEMENTS}

The first author is thankful to Central Department of Botany, Tribhuvan University. Kathmandu, Nepal for all kinds of support.

\section{REFERENCE}

Adhikari, M.K., 2009. Researches on the Nepalese mycoflora. Adhikari, K.S., Alka Basti Marg, Kathmandu, Nepal. 82 p.

Adhikari, M.K., 2012. Myxomycetes in Nepal. Bull. Dept. of Plant Resources, No. 34, 22-25.

Adhikari, M.K and V. Manandhar,1996. Fungi of Nepal, Part-I, Historical review and Myxomycotina. In Bista, M. S., S. Bhattarai and M. K. Adhikari (eds), Bull. Dept. of Plant Resources, No. 13, 20-34.

Bhatt, D.D.,1966. Preliminary list of plant diseases recorded in Kathmandu Valley. J. Nat. His. Mus., 2:13-20.

Hagiwara, H. and H. R. Bhandary,1982. Myxomycetes from central Nepal (1). In Otani, Y. (ed) Reports on Crytogamic study in Nepal. National Science Museum. Tokyo, Japan, pp 119-124. 
Nannengn-Bremekamp, N.E. and Y. Yamamoto, 1988. Stemonitls laxifila (Myxomycetes), A new species from Nepal. In Watanabe, M. and S.B. Malla (eds) Cryptogams of the Himalayas. Vol. 1: The Kathmandu Valley. National Science Museum, T. Sukuba, Japan, 29-30.

Onsberg, P.,1973. Lycogala fuscoviolaceum sp. nov. and Didermaniveum from Nepal. Bot. Tidskr., 76: 159-162.

Poelt, J.,1965. Myxomycetes aus Nepal. Khumbu Himal, 1:59-70 (in German).

Singh, N., S.C. Singh and A.R. Joshi,1977. Myxomycetes of Nepal. J. Nat. Hist. Mus., 1:215220.

Singh, S.C.,1971. Some Myxomycetes from Kathmandu Valley. Ind. Phytopath., 24:715-721. Singh, S.C. and N. Singh,1976. Myxomycetes of Nepal. J. Sc., 6:73-83.

Yamamoto, Y. and H. Hagiwara,1990. Myxomycetes from central Nepal. In Watanabe, M., and S.B. Malla (eds) 2 Cryptogams of the Himalayas. Vol. 2: Central and eastern Nepal. National Science Museum, Tsukuba, Japan, pp 33-40.

\section{Annex 1. Photographs of some species of Myxomycetes.}

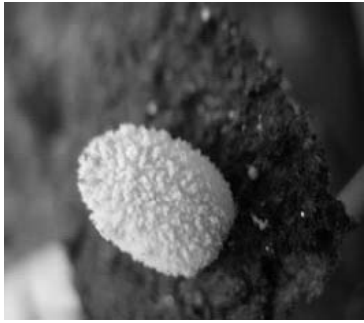

1. Fuligo cineraea

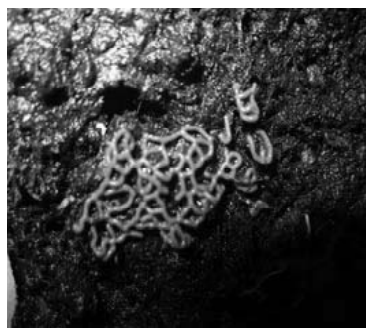

4. Hemitrichia serpula

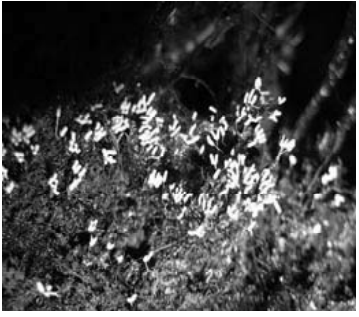

2. Arcyria cinerea

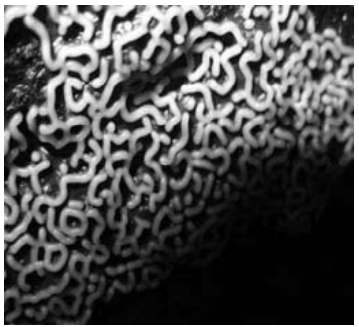

5. Didymium flexuosum

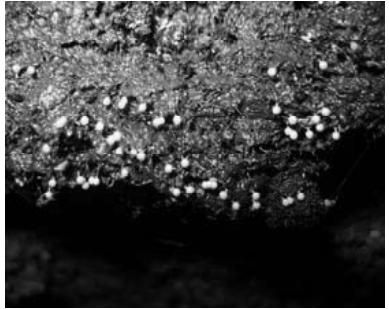

3. Physarum viride

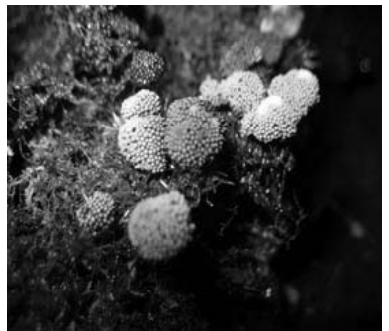

6. Tubifera microsperma

\section{AUTHORS' ADDRESS}

Ananta Bahadur Chauhan ${ }^{1}$

Arunodaya Higher Secondary School, Pharping, Kathmandu, Nepal

(email: anantachauhan@yahoo.com)

\section{Usha Budhathoki}

Central Department of Botany, Tribhuvan University, Kirtipur, Kathmandu, Nepal Mahesh Kumar Adhikari ${ }^{3}$

GPO Box no. 21758, Kathmandu, Nepal 